\title{
MAKING PARLIAMENT IRRELEVANT: A POSTCARD FROM INDIA
}

Shubhankar Dam

Separation of powers is a common feature of modern constitutions. The three principal branches of government perform distinct functions. But they aren't exclusive; the functions often overlap. This article is about one such overlap: The power of the executive to make primary legislation. Ordinarily, Parliament makes laws in India. But the Indian executive also enjoys vast legislative powers. The Indian Constitution, in Article 123, authorises the executive to promulgate ordinances if certain conditions are satisfied. These ordinances are temporary; they lapse without parliamentary ratification in due course. What about reintroducing a lapsed ordinance? It is a byzantine workaround. Is it legal? This question takes centre-stage in this analysis. Clearly, much is at stake. The Constitution confers ordinances a limited life. Repromulgation prolongs it. Repeated repromulgation prolongs it indefinitely. With the power to repromulgate, the executive becomes something more - it becomes a legislature. What remains of separation of powers then? This article does two things. It lays out the data on repromulgation at the state and national level. Then it canvases an array of analytical arguments against this practice. It argues that repromulgation is unconstitutional - it is always so. There are no exceptions. The Supreme Court, the article argues, must, therefore, reconsider its analysis on this matter. 


\section{A. THE LEGISLATIVE PRESIDENT OF INDIA}

Legislatures enact primary legislation. In India, so does the executive. Article 123 in India's Constitution authorises this: "If at any time, except when both Houses of Parliament are in session, the President is satisfied that circumstances exist which render it necessary for him to take immediate action, he may promulgate such ordinances as the circumstances appear to him to require". ${ }^{1}$ Four preliminary points are worth highlighting here. First, ordinances are the equivalent of primary legislation. ${ }^{2}$ They are not directives, rules, by-laws or subsidiary legislation of some other kind. Second, ordinances may be promulgated only if at least one House of Parliament is "not in session" 3 and the President is satisfied that "immediate action" ${ }^{4}$ is necessary. The mechanism, in effect, is designed to remedy situations of legislative urgency when Parliament is away; it is not an alternative to parliamentary legislation. Consequently, they are temporary. This is the third feature. Ordinances cease to operate six weeks after Parliament reassembles, unless they are properly enacted into law. Parliamentary scrutiny, therefore, is ex-post. The executive writes these laws, notifies them into effect, and puts them to work; only months later does Parliament get to approve or reject them. ${ }^{5}$ Lastly, in practice, the Council of Ministers decide if ordinances are necessary. At

\footnotetext{
Shubhankar Dam, Associate Professor of Law, City University of Hong Kong.

${ }^{1}$ A similar provision authorises Governors at the State (or provincial) level to do the same. See Article 213. ("If at any time, except when the Legislative Assembly of a State is in session ... the Governor is satisfied that circumstances exist which render it necessary for him to take immediate action, he may promulgate such Ordinances as the circumstances appear to him to require.”)

2 Article 123(3).

${ }^{3}$ The parliamentary calendar is decided by the Council of Ministers, often in consultation with the Speaker and the Opposition. The President formally notifies the dates when the two Houses will be in session. Under the rules of parliamentary procedure, both Houses remain in session till they are prorogued. See Lok Sabha Secretariat, Composition, Business, and Procedure, in Handbook for Members of Lok Sabha 2 (15th ed. 2009), available at http://164.100.47.132/LssNew/Members/handbook.aspx

${ }^{4}$ As I will discuss in greater detail later, the President decides if “immediate action” is necessary; it isn’t subject to judicial review. The President's determination is final.

${ }^{5}$ The political composition of the two Houses of Parliament decide if ordinances become legislation. With majority governments, they often do. But minority governments struggle to convert ordinances into legislation. There is some evidence to suggest that minority governments rely upon ordinances precisely because they are unable to legislate through Parliament. See Shubhankar Dam, Presidential Ordinances in India: The Law and Practice of Ordinances 108-110 (Cambridge University Press, New York, 2014).
} 
least in the conventional formulation, the President does not exercise legislative discretion; he or she merely promulgates the ordinances. ${ }^{6}$

The ordinance mechanism strengthens the executive's lawmaking powers in unconventional ways. It is more commonly found in presidential systems. ${ }^{7}$ But Parliament still matters in the Indian version. After all, under Article 123, ordinances are temporary. They become permanent only if Parliament enacts them into legislation. Proper parliamentary approval, therefore, is necessary for ordinances to become Acts of Parliament, and thereby, endure as law. India, it reassuringly seems, cannot permanently subject its people to laws that lack parliamentary mandate.

That, however, is a hasty conclusion. Notice that Article 123 places no numeric limits on ordinances: The President may promulgate as many as he desires. If two conditions are met at least one House of Parliament is not in session and immediate action is necessary - the President may legislate any number of ordinances. What about the same ordinance though? Does the Constitution allow the President to repeatedly promulgate the same ordinance? Is repromulgation, in other words, legal? The stakes aren’t insignificant. Repromulgation is easy and tempting; it is easier than legislating Bills through Parliament. If repromulgation is legal, one may credibly question the system of separated powers in India.

A recent repromulgation will put matters in perspective. On December 30, 2014, days after the winter session of Parliament ended, the Narendra Modi Government promulgated the Right to Fair Compensation and Transparency in Land Acquisition, Rehabilitation and Resettlement (Amendment) Ordinance 2014 (LARRO 2014). ${ }^{8}$ Consequential (and unpopular) changes were made to the law on land acquisition that was enacted with bipartisan support in 2013. ${ }^{9}$ The two Houses should have voted on the ordinance after they reassembled in February of 2015. But the Modi Government balked. A loss in the Upper House was certain; the government didn't have a majority there. ${ }^{10}$ It decided against bringing the ordinance to a vote. A parliamentary showdown was avoided. LARRO 2014 should have lapsed, consistent

\footnotetext{
${ }^{6}$ Unless otherwise mentioned, President in the rest of this analysis means the Council of Ministers.

${ }^{7}$ See John Carey \& Matthew Shugart ed, Executive Decree Authority (Cambridge University Press, Cambridge, 1998).

89 of 2014.

9 The Right to Fair Compensation and Transparency in Land Acquisition, Rehabilitation and Resettlement Act, 2013 (30 of 2013). Ramaswami Iyer, When Amendment Amounts to Nullification, Hindu, Jan. 15, 2015.

${ }^{10}$ India has a bicameral system. The Modi Government has a majority in the Lower House. But it is in a minority in the Upper House. As a result, except for certain kinds of legislation (money Bills), the government is dependent on the support of opposition parties for successfully enacting legislation.
} 
with Article 123. But the Council of Ministers had other ideas. Keen to persist with the ordinance, it repromulgated it on March 31, 2015 - days after Parliament broke for recess (LARRO 2015). ${ }^{11}$ Things were still the same six weeks later. Unable to muster a majority in the second chamber, the government repromulgated the ordinance for a third time on May 15, 2015. ${ }^{12}$ What if the government repeated this endlessly? If permitted, the practice would keep an ordinance in effect without subjecting it to a parliamentary vote - or worse, even after Parliament votes it down.

This analysis is about repromulgation of ordinances in India. The practice isn't new; governments have indulged in it for decades. In this article, I offer an empirical account of repromulgation and assess the constitutionality of the practice. While Article 123 compromises Parliament's relevance, repromulgation effectively renders it irrelevant. Why do we need a Parliament if the executive can alchemize temporary ordinances into permanent laws simply by repromulgating them? Unless deemed unconstitutional, the practice, I argue, undermines India’s parliamentary system.

The article has two main parts. In Part B, I lay out the record on repromulgation and study why governments resort to this mischievous approach. The record indicates that minority governments systematically rely on repromulgation to make up for their inability to enact permanent laws through Parliament. In Part C, I canvas a range of analytical arguments against repromulgation and assess how the Supreme Court's 1984 decision measures up against them. ${ }^{13}$ The decision is loosely reasoned and gratuitously generous; it is rather insufficient, I argue. In the concluding Part D, I suggest that the issue about repromulgation of ordinances must square up to a deeper, but simple, question - one that remains entirely unaddressed: What is repromulgation? What does it mean to repromulgate an ordinance? The best arguments against repromulgation wouldn’t matter unless we can meaningfully tell what is repromulgation to begin with.

\section{B. THE LAWLESS EXECUTIVE: REPROMULGATION IN ACTION}

\footnotetext{
111 of 2015.

12 Anon, Centre to re-promulgate land ordinance for third time, Business Standard, May 15, 2015.

${ }^{13}$ DC Wadhwa v State of Bihar AIR 1987 SC 579.
} 
The practice of repromulgating ordinances, especially at the state level, has been around for decades. Diwan Chand Wadhwa, an economist, shone light on the practice. He stumbled upon a peculiar legal trail while studying land reforms in northern India. The State of Bihar promulgated an ordinance to amend the Chota Nagpur Tenancy Act, 1908. ${ }^{14}$ The ordinance didn't become an Act. So the executive repromulgated it. And then it did it again, and again. A trend developed. The text never changed; essentially, the executive repromulgated the same ordinance. Doubtful about the constitutionality of the practice, Wadhwa investigated. A grim picture emerged. Between 1967 and 1983, Bihar had repromulgated as many as 265 ordinances. ${ }^{15}$ Of these, 60 ordinances were in effect for a year or less. About 50 were repeatedly promulgated for 5 to 10 years. Astonishingly, 13 had been kept in effect for as long as 10 to 15 years. The Council of Ministers never tabled the ordinances for a legislative vote. ${ }^{16}$ The Legislative Assembly didn’t function; it didn’t need to. By relying on Article 213 the Bihar executive had stepped into the shoes of the legislature, rendering the latter irrelevant.

Public departments in Bihar, as elsewhere in India, are known for their sloth. But they perfected an efficient arrangement by which to make this rule by ordinance possible. After every legislative session, Bihar's Legislative Affairs Department would dutifully circulate a note to relevant officials. It contained information about legislative schedules, dates on which ordinances may lapse and a reminder to contact the Law Department in a timely manner to repromulgate them. Immediately, wish lists poured in. Law Department officials vetted the ordinances before forwarding them to the Governor for assent. ${ }^{17}$ It was invariably granted. Reasons for repromulgating the ordinances weren’t mentioned. Nor did the Governor bother. The arrangement had an eerie efficiency to it; and but for Wadhwa's "accidental incursion”, India may not have found out. ${ }^{18}$

\footnotetext{
${ }^{14} 6$ of 1908 (Bengal). Bihar is one of India's poorest, and poorly governed State. Its socio-economic indicators are worse than the national average across the board. See Anon, BIMARU club still has 4 states, Times of India, Aug 13, 2015.

${ }^{15}$ D. C. Wadhwa, Re-promulgation of Ordinances: A Fraud on the Constitution of India 8-17 (Orient Longman, New Delhi, 1983).

${ }^{16}$ D. C. Wadhwa, Endangered Constitutionalism: Documents of a Supreme Court Case 9 (Gokhale Institute of Politics and Economics, Pune, 2008).

${ }^{17}$ Under Article 213, certain ordinances are reserved for the President. The vetting at the Law Department was to separate out such ordinances.

${ }^{18}$ n. 15 above, at xvii.
} 
Why did the executive resort to this well-rehearsed sham? Wadhwa didn't tell us. He noticed that this lawless approach to legislation began only in 1967. Ordinances weren’t repromulgated in Bihar until then. ${ }^{19}$ Was 1967 significant in anyway? Table 1 suggests it was. $^{20}$

Table 1: Breakdown of Bihar Assembly Election Results 1951-1980

\begin{tabular}{|l|l|l|l|l|}
\hline Election Year & Total Members & $\begin{array}{l}\text { Winner } \\
\text { (Largest Party) }\end{array}$ & $\begin{array}{l}\text { Winner } \\
\text { (Members) }\end{array}$ & $\begin{array}{l}\text { Parties Represented in } \\
\text { the Assembly }\end{array}$ \\
\hline 1951 & $330 *$ & Indian National Congress & 239 & 9 \\
\hline 1957 & $318^{*}$ & Indian National Congress & 210 & 5 \\
\hline 1962 & 318 & Indian National Congress & 185 & 7 \\
\hline 1967 & 318 & Indian National Congress & 128 & 9 \\
\hline 1969 & 318 & Indian National Congress & 118 & 13 \\
\hline 1972 & 318 & Indian National Congress & 167 & 11 \\
\hline 1977 & 324 & Janata Party & 214 & 7 \\
\hline 1980 & 324 & Indian National Congress & 169 & 10 \\
\hline
\end{tabular}

* In the 1950s, India had multi-member constituencies. As such, there were more members in State Assemblies than there were actual parliamentary seats.

The Bihar Assembly had comfortable single-party majority governments until 1967, all led by the Congress Party. Things changed thereafter. The 1967 election threw up a fractured mandate. With 128 seats, the Congress Party fell far short of a majority. Opposition parties haggled together a coalition. It lasted for two years. Four chief ministers took office in that period. Among them was Satish Singh: he bizarrely headed a government for three days - a record in India's parliamentary history. ${ }^{21}$ In 1969, new polls returned an even more divided Assembly. Another round of uncertainty followed. Ministries came and went. The coalition era was firmly in place in Bihar. Political scientist Francine Frankel writes of the struggle for power, and the attendant crisis of governance:

\footnotetext{
${ }^{19}$ n. 15 above, at 7.

${ }^{20}$ Figures in Table 1 have been calculated based on data available on the website of the Election Commission of India available at http://eci.nic.in/eci/eci.html.

${ }^{21}$ See Ashwani Kumar, Community Warriors: State, Peasants and Caste Armies in Bihar 60-77 (Anthem Press, New Delhi, 2008).
} 
The crisis of instability that overtook Bihar after the 1967 elections left the state with hardly any government. During 1967-71 Bihar experienced nine coalition ministries and three periods of President's rule (i.e. rule by the central government). Obscured by the political chaos of defections and counter-defections, numbering in the hundreds, was the new bargaining power of [certain communities] in getting a larger share of ministerial posts. ${ }^{22}$

A Congress Party-led majority government was elected in 1972. But things didn't change. The game of musical chairs continued, as factions within the party hungered for power. More chief ministers came and went. ${ }^{23}$ Political office, often short, decidedly became a means to hurried wealth. ${ }^{24}$ Governance mattered little. In that environment, repromulgating ordinances made sense. Properly enacting legislation, shepherding it through committees, and ultimately the Assembly was laborious; it meant taking basic institutions of the state seriously. Elected representatives didn’t bother. By the time Bihar's electorate voted a majority government to power in 1977, repromulgation had an established pedigree. Political parties of all persuasions, and governments, both majority and minority, found in it a convenient legislative workaround.

Interestingly, the Janata Party-led government was a majority in name only. As a motley coalition of national and regional parties, it was less stable than the parties' overall seats (214) suggested. Governance suffered; it was never a priority anyway. Repromulgation continued while anxious ministers devoted their energies to staying in office. Three years later, in 1980, the Bihar Assembly was again dissolved. The Congress Party returned to power, but with a wafer thin majority. Nothing changed as a result. The Council of Ministers went about their business; among them, repromulgating ordinances. The soft underbelly of the parliamentary form of government in India stood exposed. Especially at the provincial level, it's always been only about form (if at all).

Unfortunately, in the three decades since Wadhwa's seminal work, little scholarly progress has been made. Even preliminary data on other states aren't readily available. Is

\footnotetext{
22 Francine Frankel, “Caste Land and Dominance in Bihar” in Frankel and Rao eds., Dominance and State Power in Modern India: Decline of a Social Order Vol. 1, 99 (Oxford University Press, New Delhi, 1989). (emphasis added)

${ }^{23}$ n. 22 above.

${ }^{24} \mathrm{n}$. 22 above, at 104.
} 
Bihar a rotten exception or symptomatic of a disturbing norm? We do not know. But we do know that until 1991 the malaise didn't affect the central government in New Delhi; the repromulgation virus stayed quarantined in the state capital(s). The central government repromulgated an ordinance for the first time in 1992. A trend soon emerged. The 1990s altogether witnessed 53 cases of repromulgation. There were 196 ordinances in all in the 1990s, with almost 25 per cent repromulgation.

The trend wasn't an accident. In the 1990s, India experienced a dose of Bihar: legislative instability fueled by minority governments. V.P. Singh became Prime Minister in 1989; he led India's first minority government. ${ }^{25}$ There were seven more prime ministers over the next decade. ${ }^{26}$ As governments with poor numbers in Parliament struggled with legislation, they turned to ordinances, first to bring laws into effect, and then to keep them in effect by repromulgating them. P. V. Narasimha Rao (1991-96), H. D. Deve Gowda (1996), Inder Kumar Gujral (1997) and Atal Bihari Vajpayee (1997-1998, 1999-2004) freely resorted to repromulgation as ordinary lawmaking proved onerous. ${ }^{27}$

Repromulgation is a common practice now. At least in Bihar and in the Central Government, the abuses are well documented. But questions remain. After all, Articles 123 and 213 were designed to help governments make temporary laws because legislatures couldn’t. But governments now deploy them to make laws legislatures perhaps wouldn’t. Worse, by invoking them strategically, governments are effectively making permanent laws that legislatures wouldn't. Is that constitutional?

The question isn't a new one. In D.C. Wadhwa $v$ State of Bihar ${ }^{28}$, the Supreme Court dealt with it. In the next section, I shall outline a series of arguments against repromulgation, and then contrast the Court's approach to the question.

\section{Analytical Challenges to Repromulgation}

Notice that Article 123 is silent about repromulgation. It doesn’t provide for it; equally, it doesn't disallow it. The analytical challenge is to make sense of this silence. Is it permissive? Or, is the silence prohibitive? Perhaps the strongest argument in favour of a permissive

\footnotetext{
25 Technically, India’s first minority government came in 1969. But it was a majority government that was reduced to a minority because of a split in the ruling Congress Party.

${ }^{26}$ n. 5 above, at 109 .

27 See Presidential Ordinances 1950-2009 (Lok Sabha Secretariat, New Delhi, 2011).

${ }^{28}$ AIR 1987 SC 579.
} 
reading is the lack of explicit prohibition. The Constitution grants a power to the executive. "Reuse" isn't explicitly barred. Therefore, it may be reused. To forcefully read limitations into the provision is to do violence to it. It is a simple argument; it is also incorrect.

The ordinance method is an exception; parliamentary legislation is the norm. If so, Article 123 isn’t the only exception. Much of India's Constitution is an uneasy mix of norms and exceptions. This is true of provisions that confer rights, and those that define institutional boundaries. How has the Supreme Court navigated such provisions?

Article 75(5) is a good example. In India, ordinarily, only members of the legislature are eligible for ministerial appointments. ${ }^{29}$ But Article 75(5) introduces an exception: “A Minister who for any period of six consecutive months is not a member of either House of Parliament shall at the expiration of that period cease to be a Minister”. Introduced in the Government of India Act, $1935,{ }^{30}$ the exception, largely speaking, is a departure from British parliamentary practice.

In SR Chaudhuri v State of Punjab ${ }^{31}$, the exception was debated. Tej Singh was appointed a minister. He wasn't a member of the Assembly; and he did not become one even after six months. He resigned. Later on a new Chief Minister took office during the term of the same Assembly. Singh was again inducted as an unelected minister. This second appointment was challenged. The Supreme Court invalidated it. Much of the Court's reasoning drew from the nature of parliamentary system and the idea of responsible government. In such a system, a Council of Ministers is a subset of the representative chambers; it comes from - and is accountable to - the legislature. To allow repeated ministerial appointments through an extraordinary method would "defeat and subvert the basic principle of representative and responsible Government”32. Therefore, despite the lack of explicit prohibition, such appointments, the Court concluded, are a one-off thing; persons may from profit from it only once during the tenure of an Assembly. ${ }^{33}$ This reasoning keeps both the norm (ministers' membership of the legislative branch) and the exception (non-member appointments) relevant: the latter doesn't swallow the former. Similar considerations must guide our assessment of repromulgation in Article 123.

\footnotetext{
${ }^{29}$ India Const. Article 75(3).

3025 \& 26 Geo. 5 c. 42.

${ }^{31}$ (2001) 7 SCC 126.

32 Ibid [35].

${ }^{33}$ Ibid. Ordinarily, lower Houses in India have a five-year term, though they may be dissolved earlier.
} 
Secondly, to repromulgate is to effectively extend the life of an ordinance. An ordinance "ceases to operate" six weeks after the two Houses reassemble, except if it is converted into an Act by then. Repromulgation sidesteps this limitation. Now consider some other exceptions in the Constitution; particularly, Articles 352, 356 and 360. Their wording has interpretative relevance for Article 123. The provisions endow the executive with emergency powers. Article 352 authorises the President to proclaim a general emergency (because of war, external aggression, or armed rebellion). Such proclamations initially remain in effect for a month. ${ }^{34}$ That may increase to six months if both Houses of Parliament approve. ${ }^{35}$ Further extensions are also possible; there are no limits. But parliamentary resolutions are needed for each extension. ${ }^{36}$ Article 356 is different. It authorises the President to take over the administration of a State (province) if he is satisfied that the "administration of the State cannot be carried on in accordance with [the] provisions of the Constitution”. Ordinarily, these proclamations have a two-month life. With parliamentary backing, they remain in effect for six. ${ }^{37}$ This too may be extended, but only once. Overall, such proclamations may not be extended beyond one year, except in exceptional cases. ${ }^{38}$ Article 360 is still different. It deals with financial emergency. Under it, the executive may don sweeping financial powers for two months. But if the two Houses approve the declaration, it remains in effect indefinitely. A new proclamation is needed to revoke or modify it.

These provisions have a precise quality to them. They demonstrate that in creating exceptions, the Constitution was careful to define their terms. The provisions clearly outline when, how and how often these exceptions may be recycled. Article 123 stands in contrast. It creates an exception but says nothing about extensions. Read in context, the silence, therefore, is prohibitive.

Repromulgation also undermines separation of powers. That much is obvious: It renders Parliament irrelevant. Effectively, the executive may make permanent legislation without legislative input or approval. But the theory of separation of powers and the practice of a parliamentary form of government are odd friends. The latter, Walter Bagehot famously observed, demonstrates a "near complete fusion of the executive and legislative powers" 39 . Alert to this formulation, the Indian Constitution does not mention the concept; only an

\footnotetext{
${ }^{34}$ Article 352(4).

${ }^{35}$ Article 352 (5).

${ }^{36}$ Ibid.

${ }^{37}$ Article 356(4).

${ }^{38}$ Article 356(5).

${ }^{39}$ Walter Bagehot, The English Constitution 67-68 (1867).
} 
oblique reference appears in Article 50: "The State shall take steps to separate the judiciary from the executive in the public services of the State”. Does it then matter that repromulgation undermines separation of powers?

It does. Whatever it's conceptual animosity with the parliamentary form of government, separation of powers now has an exalted pedigree in India. Constitutional analyses are often done in its name. In Kesavanand Bharti $v$ State of Kerala ${ }^{40}$, four judges (of the seven who constituted the majority) listed separation of powers as a "basic feature" of the Constitution. ${ }^{41}$ That feature, they said, is so essential to the identity - and integrity - of the Constitution that any attempt to abrogate or tinker with it would be unconstitutional. Developed in 1973, the basic structure doctrine was meant to test the exercise of constituent power (and constitutional amendments). But two decades later it was extended to executive power (and executive actions).

The extension was innovated in S.R. Bommai v Union of India ${ }^{42}$. Six State governments were dismissed between 1989 and 1993 under Article 356. The Supreme Court upheld three of those dismissals. The State governments, a majority reasoned, had violated principles of secularism by their executive actions, and inactions. ${ }^{43}$ Constitutional provisions may not have been violated; but certain basic features had been, including democracy and secularism. ${ }^{44}$ As a result, the basic structure theory is no longer limited to constitutional amendments. As a test of legality, it applies to executive actions as well.

What about legislative power? In India, legislation cannot violate constitutional provisions. But may courts also invalidate legislation because they violate (supposedly) important features of the Constitution? Sharp disagreements exist on this matter. Four decades of judicial analyses haven’t produced a satisfactory consensus. Broadly, two views exist. In Indira Gandhi v Raj Narain, the Court reasoned to keep legislative power immune from any basic structure scrutiny. ${ }^{45}$ Two years later in State of Karnataka v. Union of India judges took a contrary view. Primary legislation, they said, must satisfy the demands of the basic structure doctrine. ${ }^{46}$ Because State of Karnataka was later overruled on other issues,

\footnotetext{
401973 (4) SCC 225.

${ }^{41}$ They are Judges Sarv Sikri, Shelat and Grover, Jaganmohan Reddy.

42 (1994) 3 SCC 1.

43 Ibid [365].

${ }^{44}$ Ibid [28]; [64]; [87]; [124].

451975 Supp SCC 1 [134].

461977 (4) SCC 608 [125].
} 
this finding hasn't received a close reading. Many decisions continue to rely on the Indira Gandhi view. ${ }^{47}$ But recently the Court has hinted at making legislative power subject to the basic structure test again. ${ }^{48}$

At least some decisions suggest that the basic structure doctrine constrains legislative power too. How does it affect repromulgation? Presidents exercise legislative power in promulgating ordinances. ${ }^{49}$ This much is beyond doubt. And to repromulgate, we know, is to usurp the legislative function, and render Parliament irrelevant. That undermines separation of powers. This is another reason to hold repromulgation unconstitutional: the President cannot exercise his legislative powers in a way that violates the basic structure of the Constitution. Notice a difference here though. Basic structure arguments regarding Parliament's legislative power (Acts) relate to content: specific legislative provisions may violate the basic structure. But basic structure arguments regarding the President's legislative power (ordinances) should also apply to the manner of legislation. To deem repromulgation unconstitutional is to say that ordinances cannot be made in a certain way. Their contents aren't at issue here.

What I have shown so far is that a rich arsenal of arguments can help us navigate questions about the constitutionality of repromulgation. How have courts faired? In D.C. Wadhwa v State of Bihar ${ }^{50}$, the question was squarely before the Supreme Court. Inspired by the plaudits his book won, Wadhwa moved a Public Interest Petition. Repromulgation in Bihar was unlawful, he argued. The Supreme Court agreed. Makers of the Constitution intended ordinances to have temporary lives, the judges reasoned. For the executive to prolong them "without going to the Legislature" would tantamount to "usurping the lawmaking function". ${ }^{51}$ That in turn would subvert the democratic process which lies at the "core of [India's] constitutional scheme”. ${ }^{52}$ A little later in the decision, the Court admonished the executive more strongly: to sustain an ordinance by repromulgating it with "substantially the

\footnotetext{
${ }^{47}$ Kuldip Nayar v Union of India 2006 (7) SCC 1; Ashok Thakur v Union of India 2008 (6) SCC 1.

${ }^{48}$ Nagaraj v Union of India (2006) 8 SCC 212; Madras Bar Association v Union of India 2014 SCCOnline SC 771.

${ }^{49}$ Venkata Reddy v. State of Andhra Pradesh AIR 1985 SC 724.

${ }^{50}$ AIR 1987 SC 579.

${ }^{51}$ Ibid [6].

${ }^{52}$ Ibid.
} 
same provisions" is to exercise power colourably. It is a "fraud on the constitution", the Court ominously concluded. ${ }^{53}$

The basics are correct, and so is the conclusion. But clearly much more could have been said. The decision lacked analytical rigor. The sloppiness particularly shines through in the exception the Court gratuitously sliced out. ${ }^{54}$ Repromulgation is lawful, the judges said, if a government is unable "to introduce and push through" a Bill to convert an ordinance. The government’s inability may be for a number of reasons: “The Legislature [may have] too much legislative business", or the time at its disposal may be short. ${ }^{55}$ In other words, if the legislature is too busy or a session is too short, repromulgation is justified.

This makes little sense. Who will judge busyness? Courts cannot do so; legislative chambers are authorized to conduct their business as they deem fit. ${ }^{56}$ Nor can the Court insist on legislative sessions of particular duration. Article 85 lays down the minimum frequency with which legislative chambers must convene: "The President shall from time to time summon each House of Parliament to meet at such time and place as he thinks fit, but six months shall not intervene between its last sitting in one session and the date appointed for its first sitting in the next session”. This is the sessional floor, the minimum, legislators must satisfy. Can the Court insist on longer sessions beyond what is constitutionally prescribed?

The reasoning has other problems too. Prioritizing other legislation should be evidence that any pending ordinance wasn’t immediately necessary. The executive in India has complete control over legislative sessions, their durations and the business agenda. ${ }^{57}$ The Council of Ministers decide which matters to list and when. By the Court's reasoning, Ministers may justify repromulgating an ordinance simply by truncating it from the business agenda or by shortening the legislative session. The Modi Cabinet resorted to this with LARRO 2014. Cognizant of its lack of numbers in the Upper House, the ordinance wasn't listed on the agenda; it was never brought to a vote. But it was repromulgated soon after the House went into recess during the budget session. Apparently, a "fraud on the Constitution" may alchemize into lawful conduct just by inaction. Surely, that cannot be. The proper (parliamentary) response to a busy legislative calendar is a longer session; not repromulgation.

\footnotetext{
53 Ibid. (emphasis added)

${ }^{54}$ A. Noorani, "Supreme Court And Ordinances”, 22(9) Economic And Political Weekly 357-358 (1987).

55 Ibid

56 See Article 122. Ramdas Athwale v Union of India (2010) 4 SCC 1.

${ }^{57}$ Article 85(1). The Constitution doesn't say for how long legislatures should be in session, except that they should meet at least once every six months.
} 
Unlike Bihar, the central government began repromulgating ordinances only in 1992. This is counterintuitive; the practice was already unconstitutional by 1987 . Why did it at all begin? And then take dangerous proportions? Clearly, it has to do with the exceptions. DC Wadhwa, it must be said, encouraged rather than prohibited repromulgation. The 1990s speak for themselves. Minority governments relished in Article 123. They took it as an alternative mechanism, unable to enact legislation through the normal route. Political expediency motivated these ordinances and their repeat versions, not urgency. Governments though were always careful to claim the "proper" excuse: the Houses were too busy to deal with the ordinances. In repromulgating LARRO 2014, the Modi Government, it turns out, was rehearsing an old script.

In Gyanendra Kumar v Union of India, ${ }^{58} 10$ repromulgation by the Narasimha Rao Cabinet came under judicial scanner. Two lawyers petitioned the Delhi High Court to pierce the Cabinet veil and see the ordinances for what they were: a "fraud on the Constitution". The government quickly took refuge in the Wadhwa exception: Because of "heavy and urgent" workload, "the Bills could not be debated upon" in Parliament. ${ }^{59}$ Repromulgation, therefore, was necessary. The Court agreed. Veracity of those claims remained untested; the judge posed no further questions. Merely uttering the exception seems to satisfy the Wadhwa exception.

Little wonder then that repromulgation has a queer status in India. It is unconstitutional in theory, and common in practice. Theory and practice will be in sync only if the Wadhwa reasoning gives way to a more rigorous analysis. Recall the verdict in SR Chaudhuri. A nonmember may be appointed minister only once in the life of an Assembly. There are no caveats. Non-members, the Court did not say, may be reappointed under Article 75 if other qualified persons aren't available to serve as ministers. In fact, “constitutional restraints”, the Court sternly pointed out, "must not be ignored or bypassed if found inconvenient or bent to suit 'political expediency'”, ${ }^{60}$ This uncompromising approach should govern ordinances too. Repromulgation contravenes Article 123, and undermines the basic structure. It is a serious violation which legislative exigencies or busyness can neither soften nor make right.

\section{IN LIEU OF CONCLUSION}

\footnotetext{
58 AIR 1997 Del 58.

${ }^{59}$ Ibid [9].

${ }^{60}$ n. 31 above [38].
} 
Repromulgation is unconstitutional; it is so under all circumstances. This is a demanding conclusion. But it must face up to the possibility of disguised repromulgation.

What, after all, is a repromulgated ordinance? An identical law is an obvious example. Introducing the same ordinance, without any changes, clearly amounts to repromulgation. But a revised ordinance: is that repromulgation, too? Take LARRO 2015. It wasn't the same as LARRO 2014. Nine changes were made to it, some of them rather consequential. Almost all amendments were incorporated to gain more allies (and votes) in the Upper House. It was neither the same law, nor a completely revised one. Given these changes, does LARRO 2015 count as repromulgation? A simple option is to look at the title: Does the original ordinance and the repromulgated versions bear the same name? That has been the case thus far. All repromulgated ordinances have kept their original titles. But this mechanical route doesn’t take us far. With little effort, the same ordinance may be introduced with a new title.

Perhaps a better option is to focus on the contents of the ordinances. DC Wadhwa sympathized with such an approach. The judges spoke of invalidating "substantially similar" ordinances. ${ }^{61}$ In Endangered Constitutionalism, Wadhwa too seconded this approach. He proposed a proviso to Articles 123 and 213: "Notwithstanding any provision contained in this Constitution ... no Ordinance promulgated by the President shall be repromulgated by him nor any Ordinance reproducing substantially the provisions of the repealed or lapsed Ordinance shall be promulgated by him under any circumstances". ${ }^{2}$ Unlike the title test, the substantial similarity test is not a mechanical one. It seeks to really understand how - and the extent to which - a government has abused the ordinance mechanism. But its strength is also its weakness. Because it isn’t a self-executing test, we now need a further standard by which to assess "substantial similarity”. But any such test will likely prove inadequate; it will do little more than incubate litigation and uncertainty. Ordinances will remain in limbo for long durations while their similarities and differences are judicially dissected.

Perhaps an objective test is to look at legislative entries. The Seventh Schedule of the Indian Constitution distributes legislative power between the Centre and the States. It has three lists: Central, State, and Concurrent. The Centre and the States have exclusive authority to enact legislation on entries (or topics) mentioned in the Central and State Lists respectively. However, both share jurisdiction over the Concurrent List. An ordinance should

\footnotetext{
${ }^{61}$ n. 51 above.

62 n. 16 above, at 293.
} 
count as repromulgation if the original and latter versions are traced to the same legislative entry. LARRO 2014 and 2015 were both about land acquisition and compensation. That makes it a repromulgation, and therefore unconstitutional. This way of judging constitutionality accounts for the weaknesses of both the title and the substantial similarity tests. It denies the executive the opportunity to repromulgate ordinances simply by changing their titles. But it also saves us from the argumentative quicksand that a substantial similarity test will necessarily draw us into.

“There can be no liberty”, Montesquieu, the high priest of separation of powers, feared, if "legislative and executive powers are united in the same person or in the same body of magistrates”. ${ }^{63}$ Article 123 does exactly that: It authorises the executive to enact primary legislation. Such laws though were meant to be temporary. Repromulgation sidesteps that limitation, and makes ordinances permanent. Montesquieu's prediction hasn't descended on India, yet. Liberty remains. But the threat of its demise too remains. Unless reasoned away from the Constitution in theory and abandoned in practice, repromulgation may ultimately bear out the French prognostication, in India.

${ }^{63}$ Montesquieu, Charles de Secondat, baron de. The Sprit of Laws (c.1748). 